\title{
Chemistry, antiproliferative properties, tumor selectivity, and molecular mechanisms of novel gold(III) compounds for cancer treatment: a systematic study
}

\author{
Angela Casini · Gerhard Kelter · Chiara Gabbiani · \\ Maria Agostina Cinellu • Giovanni Minghetti · \\ Dolores Fregona $\cdot$ Heinz-Herbert Fiebig $\cdot$ Luigi Messori
}

Received: 29 April 2009/Accepted: 6 June 2009/Published online: 20 June 2009

(c) SBIC 2009

\begin{abstract}
The antiproliferative properties of a group of 13 structurally diverse gold(III) compounds, including six mononuclear gold(III) complexes, five dinuclear oxobridged gold(III) complexes, and two organogold(III) compounds, toward several human tumor cell lines were evaluated in vitro using a systematic screening strategy. Initially all compounds were tested against a panel of 12
\end{abstract}

Electronic supplementary material The online version of this article (doi:10.1007/s00775-009-0558-9) contains supplementary material, which is available to authorized users.

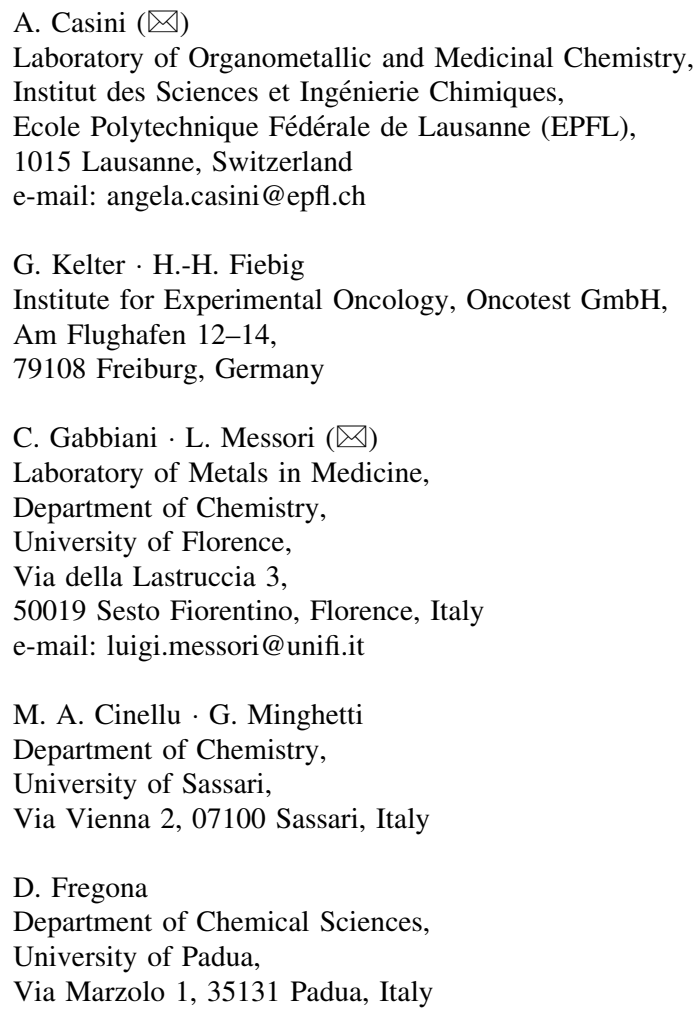

human tumor cell lines, and the best performers were tested against a larger 36-cell-line panel. Very pronounced antiproliferative properties were highlighted in most cases, with cytotoxic potencies commonly falling in the low micromolar-and even nanomolar-range. Overall, goodto-excellent tumor selectivity was established for at least seven compounds, making them particularly attractive for further pharmacological evaluation. Compare analysis suggested that the observed antiproliferative effects are caused by a variety of molecular mechanisms, in most cases "DNA-independent," and completely different from those of platinum drugs. Remarkably, some new biomolecular systems such as histone deacetylase, protein kinase $\mathrm{C} /$ staurosporine, mammalian target of rapamycin/rapamycin, and cyclin-dependent kinases were proposed for the first time as likely biochemical targets for the gold(III) species investigated. The results conclusively qualify gold(III) compounds as a promising class of cytotoxic agents, of outstanding interest for cancer treatment, while providing initial insight into their modes of action.

Keywords Anticancer drug .

Structure-function relationship

\section{Introduction}

Presently, platinum drugs are playing a major role within established medical treatments of cancer [1-3]. The wide clinical success of platinum compounds has prompted a great deal of interest in other platinum and non-platinum metallodrugs that might exhibit comparable cytotoxic properties, hopefully accompanied by a different pattern of antitumor specificities and by a more favorable toxicological and/or pharmacological profile. Thus, various classes 
of metal compounds were intensely investigated during the last three decades as potential anticancer agents based on several different metals (e.g., ruthenium, tin, palladium, titanium, gold, copper). The current investigative efforts and the state of the art in the field of anticancer metal complexes have been summarized in a few excellent review articles and books [4-9].

In particular, during the last 10 years, much interest has focused on gold(III) compounds as a number of newly synthesized gold(III) metallodrugs turned out to display appreciable stability under physiological-like conditions while being highly cytotoxic in vitro toward selected human tumor cell lines $[10,11]$. The first gold(III) complexes of the new generation were described by Parish et al. $[12,13]$ in the 1990s. The acceptable solution stability of these gold compounds facilitated extensive pharmacological testing, both in vitro and in vivo, with encouraging results. Subsequently, several other classes of cytotoxic gold(III) compounds were developed in a few laboratories worldwide and were found to exhibit very attractive biological profiles (e.g., gold(III) dithiocarbamates [14] and gold(III) porphyrins [15]).

On the whole, these studies indicated that most of the newly synthesized gold(III) species possess sufficient stability in solution and show pronounced antiproliferative effects in vitro, with $\mathrm{IC}_{50}$ (drug concentration needed to reduce cell viability to $50 \%$ of the control value) values often falling in the low micromolar and even nanomolar range [16]. Moreover, on the basis of the comparative analysis of a series of structurally related metal complexes, it could be established that the presence of a gold(III) center typically results in the appearance of a more pronounced cytotoxic behavior [17].

Some initial indications concerning the possible mechanism of action of novel gold(III) compounds were obtained. On the basis of the overall modest binding affinities usually measured for double-helix DNA [18], it seemed unlikely that all these gold compounds might work analogously to cisplatin (cis- $\left.\left[\mathrm{PtCl}_{2}\left(\mathrm{NH}_{3}\right)_{2}\right]\right)$, i.e., by producing a direct (coordinative) lesion on DNA eventually leading to cell apoptosis. On the other hand, it was found that most of the newly synthesized gold(III) compounds exhibited a high reactivity toward proteins and induced large proapoptotic effects in cell models, probably mediated by a direct interference with the mitochondrial functions $[19,20]$. Hence, the idea that a major biochemical mechanism for cytotoxicity might be a direct "mitochondrial insult" through alteration of selected proteins was proposed, similar to that of a number of gold(I) compounds [21-25]. This view, now supported by recent additional studies $[25,26]$, seems to represent a very reasonable and well-grounded working hypothesis to rationalize the cytotoxicity of gold(III) compounds. Notwithstanding, different and alternative kinds of molecular mechanisms have been proposed in the meantime for other families of cytotoxic gold(III) compounds (e.g., proteasome inhibition for gold(III) dithiocarbamates [10, 27] or modulation of cell death by gold(III) porphyrins through the mitogen-activated protein kinase family proteins [28]).

The results described above imply that gold(III) compounds possess a considerable potential as cytotoxic and, in particular, antitumor agents. However, most data concerning their antiproliferative effects have been obtained under quite different and heterogeneous experimental conditions; in addition, the cytotoxic effects of novel gold(III) compounds were measured on very few-and often different-tumor cell lines; in some cases just a single human tumor cell line was examined.

We thought that these circumstances might weaken the current view of gold(III) compounds as a new class of effective cytotoxic agents, suitable for cancer treatment. Thus, we decided to extend their biological characterization and undertake a more robust and systematic investigation of the cell growth inhibition properties of a representative ensemble of gold(III) compounds working on a wider and common panel of human tumor cell lines.

Notably, the present study focused on a variety of structurally different classes of gold(III) complexes, which were developed and studied in our laboratories, comprising the following: a dithiocarbamate derivative $\left[\mathrm{Au}(\mathrm{esdt}) \mathrm{Br}_{2}\right]$ (A1) [29] (where esdt is ethylsarcosinedithiocarbamate); polyamine derivatives $\left[\mathrm{Au}(\mathrm{dien}) \mathrm{Cl}^{-} \mathrm{Cl}_{2}\right.$ (B1) [30] and [Au(cyclam)] $\left(\mathrm{ClO}_{4}\right)_{2} \mathrm{Cl}$ (B2) [30] (where dien is diethylentriamine and cyclam is 1,4,8,11-tetraazacyclotetradecane); polypyridine derivatives $\left[\mathrm{Au}(\mathrm{bipy})(\mathrm{OH})_{2}\right]\left(\mathrm{PF}_{6}\right) \quad(\mathbf{C 1}) \quad[31]$, $\left[\mathrm{Au}(\right.$ phen $\left.) \mathrm{Cl}_{2}\right] \mathrm{Cl}(\mathbf{C 2})[30,32]$, and $[\mathrm{Au}($ terpy $) \mathrm{Cl}] \mathrm{Cl}_{2}(\mathbf{C 3})$ [30] [where bipy is $2,2^{\prime}$-bipyridine (L1), phen is 1,10 -phenathroline, and terpy is $2,2^{\prime}: 6^{\prime}, 2^{\prime \prime}$-terpyridine]; cyclometallated organogold derivatives $\left[\mathrm{Au}\left(\right.\right.$ bipy $\left.\left.^{\mathrm{dmb}}-\mathrm{H}\right)(\mathrm{OH})\right]\left(\mathrm{PF}_{6}\right)$ (D1) [31] and $\left[\mathrm{Au}\left(\right.\right.$ bipy $\left.\left.^{\mathrm{dmb}}-\mathrm{H}\right)\left(\mathrm{NHC}_{6} \mathrm{H}_{3} \mathrm{Me}_{2}-2,6\right)\right]\left(\mathrm{PF}_{6}\right)$ (D2) [33] [where bipy ${ }^{\mathrm{dmb}}$ is 6-(1,1-dimethylbenzyl)-2,2'bipyridine (L2)]; and dinuclear oxo-bridged complexes $\left.\left[\mathrm{Au}_{2}(\text { bipy })_{2}(\mu-\mathrm{O})_{2}\right]\left(\mathrm{PF}_{6}\right)_{2}(\mathbf{E} \mathbf{1}), \mathrm{Au}_{2}\left(\text { bipy }^{\mathrm{Me}}\right)_{2}(\mu-\mathrm{O})_{2}\right]\left(\mathrm{PF}_{6}\right)_{2}$ (E2), $\left.\mathrm{Au}_{2}\left(\text { bipy }^{\text {neoPen }}\right)_{2}(\mu-\mathrm{O})_{2}\right]\left(\mathrm{PF}_{6}\right)_{2}(\mathbf{E 3}), \mathrm{Au}_{2}\left(\text { bipy }^{\mathrm{oXy}}\right)_{2}$ $\left.(\mu-\mathrm{O})_{2}\right]\left(\mathrm{PF}_{6}\right)_{2}(\mathbf{E} 4)$, and $\left.\mathrm{Au}_{2}\left(\text { bipy }^{\mathrm{Me}, \mathrm{Me}}\right)_{2}(\mu-\mathrm{O})_{2}\right]\left(\mathrm{PF}_{6}\right)_{2}(\mathbf{E 5})$ [34] [where bipy ${ }^{\mathrm{Me}}$ is 6-methyl-2,2'-bipyridine, bipy ${ }^{\text {neoPen }}$ is 6-neopentyl-2,2'-bipyridine, bipy ${ }^{\mathrm{oXyl}}$ is 6-(2,6-dimethylphenyl)-2,2' -bipyridine, and bipy ${ }^{\mathrm{Me}, \mathrm{Me}}$ is 6,6'-dimethyl-2,2' bipyridine] (see Fig. 1).

The gold(III) compounds were analyzed at Oncotest according to specific screening strategies of new anticancer agents developed as described in "Materials and methods" (see also http://www.oncotest.de). Initially, a standard 12cell-line panel was used, which allowed the various compounds to be ranked according to their average cytotoxic potency. Afterwards, the best performers were assayed on a 
Fig. 1 Gold compounds and bipyridine-based ligands used in this work<smiles>CCOC(=O)CN(C)C1=[SH][Ge](Br)(Br)S1</smiles>

A1<smiles>CCN1CCN[Al]1Cl</smiles>

B1

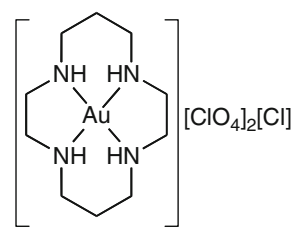

B2<smiles>CC(C)CC1=CC=CC2=C3C=CC=CN3[Si](O)(O)N12</smiles>

C1

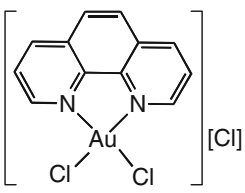

C2

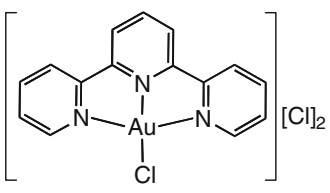

C3

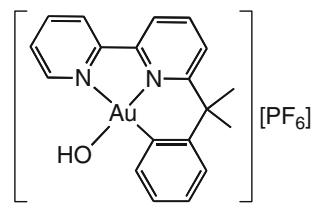

D1<smiles>Cc1ccccc1N[Al]1(c2ccccc2C(C)(C)C(C)C)N=C2C=CC=C2c2cccn21</smiles>

D2

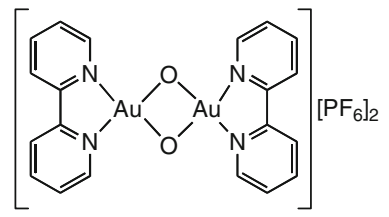

E1

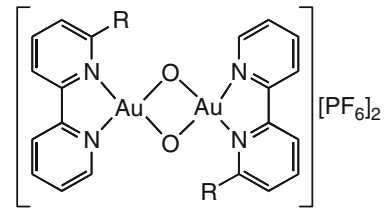

$\mathrm{R}=\mathrm{Me} ; \mathrm{E} 2$ $\mathrm{R}=\mathrm{CH}_{2} \mathrm{CMe}_{3} ; \mathrm{E} 3$ $\mathrm{R}=\mathrm{C}_{6} \mathrm{H}_{3} \mathrm{Me}_{2}-2,6 ; \mathrm{E} 4$<smiles></smiles>

E5

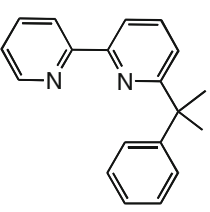

bipy $^{\mathrm{dmb}}$

F1

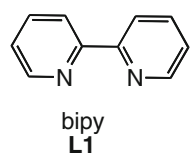

L2

wider 36-cell-line panel. This latter experiment allowed us to assess, with a higher reliability, the selectivity of the observed antitumor effects. By combining the results of cytotoxicity and selectivity tests, we achieved an overall scoring of all compounds analyzed.

Finally, the results of the 36-cell-line experiments were examined through the Compare algorithm [35, 36], to gain specific mechanistic information on each complex. Activity patterns of the gold compounds were correlated to the patterns of the approximately 100 reference compounds as tested in the Oncotest 36-cell-line panel (see the electronic supplementary material). Similarity in the cytotoxicity pattern often implies similarity in the mechanism of action, mode of resistance, and possibly molecular structure [37]. Overall, this approach is aimed at establishing initial structure-function relationships, of potential interest for further drug design and development. 


\section{Materials and methods}

Chemistry

Compounds were prepared according to literature procedures (see the references throughout the text).

Tumor cell lines

Twenty-four out of the 36 cell lines were established from patient-derived tumor xenografts passaged subcutaneously in nude mice [38]. The origin of the donor xenografts has already been described $[39,40]$. The other 12 cell lines were commercially available and purchased from ATCC (Rockville, MD, USA) or DSMZ (Braunschweig, Germany) or were kindly provided by the NCI (Bethesda, MD, USA). The 36-cell-line panel included 14 different tumor histotypes, each represented by one to six cell lines (see the electronic supplementary material). All cells were grown at $37{ }^{\circ} \mathrm{C}$ in a humidified atmosphere $\left(95 \%\right.$ air, $\left.5 \% \mathrm{CO}_{2}\right)$ in RPMI 1640 medium (PAA, Cölbe, Germany) supplemented with $10 \%$ fetal calf serum (PAA) and $0.1 \mathrm{mg} / \mathrm{ml}$ gentamicin (PAA).

Cytotoxicity assays (monolayer assay) and Compare analysis

A modified propidium iodide assay [41] was used to assess the effects of compounds. Tumor-derived cell lines were incubated in 96-well plates. After 1 day, the compounds under test were added to the plates at five concentrations in the range from 0.001 to $10 \mu \mathrm{g} / \mathrm{ml}(\mathbf{C 3})$ or from 0.01 to $100 \mu \mathrm{g} / \mathrm{ml}$ (the other 15 test compounds) and left for a further 4 days. The inhibition of proliferation was determined by measuring the DNA content using an aqueous propidium iodide solution $(7 \mu \mathrm{g} / \mathrm{ml})$. Fluorescence was measured using a Cytofluor 4000 instrument. All compounds were tested in two to four independent experiments. In each experiment, all data points were determined in triplicate.

The Compare algorithm uses in vitro activity data to obtain clues as to the mechanism of action of a test compound $[35,36]$. The individual $\mathrm{IC}_{50}$ and $\mathrm{IC}_{70}$ (drug concentration needed to reduce cell viability to $30 \%$ of the control value) values of the test compounds in 36 test cell lines obtained in the monolayer assay were correlated to the corresponding $\mathrm{IC}_{50} / \mathrm{IC}_{70}$ values for 110 standard agents determined in these 36 cell lines. Data for these standard agents are available in the electronic supplementary material. These standard agents represent the main mechanisms of action of current anticancer drugs. Similarities between the sensitivity pattern of a test compound and those of standard drugs are expressed quantitatively as Spearman correlation coefficients [42]. High correlations $(\rho>0.6)$ between the sensitivity patterns of two compounds (referred to as Compare-positive) are indicative of similar mechanisms of action. Low correlations between the sensitivity profile of a test compound and the profiles of all standard compounds (referred to as Compare-negative) indicate that the mechanism of action of the test compound is not represented by the selected standard compounds.

\section{Results}

\section{Chemistry}

\section{Structural chemistry}

The 13 gold(III) complexes chosen for the present study are shown in Fig. 1. Basically, the tested ensemble includes five classic gold(III) coordination compounds B1, B2, C1, C2, and C3; a gold(III) dithiocarbamate complex A1; two cyclometallated derivatives D1 and D2, containing one carbon-gold bond; and five oxo-bridged dinuclear complexes E1, E2, E3, E4, and E5. In addition, for comparison purposes, a classic gold(I) complex, namely, [(2,3,4,6tetra- $O$-acetyl-1-(thio- $\kappa \mathrm{S}$ )- $\beta$-D-glucopyranosato)(triethylphosphine) gold(I)] (auranofin) F1 (Fig. 1), as well as representative free ligands- bipy (L1) and bipy ${ }^{\mathrm{dmb}}(\mathbf{L 2})$ were analyzed (Fig. 1). In Table 1 a collection of relevant chemical data for each compound is presented.

All the above-mentioned gold compounds have been investigated in detail during the last 20 years. Crystallographic data were indeed reported for most of them, as shown in Table 1 [43-46]. The crystal data for $\mathbf{A 1}$ have been deposited very recently [20], and for $\mathbf{C 1}$ and D1 crystal data of the closely related compounds $\left[\mathrm{Au}(\mathrm{bipy})(\mathrm{OMe})_{2}\right] \mathrm{PF}_{6}[47]$ and $\left[\mathrm{Au}\left(\right.\right.$ bipy $\left.\left.^{\mathrm{dmb}}-\mathrm{H}\right) \mathrm{X}\right] \mathrm{PF}_{6}(\mathrm{X}$ is $\mathrm{Cl}$ [48], SPh [49], $\mathrm{NHC}_{6} \mathrm{H}_{3} \mathrm{Me}_{2}-2,6$ [50]) are available.

Compounds A1, B1, B2, C1, C2, and $\mathbf{C 3}$ are classic mononuclear gold(III) complexes of square-planar geometry. In all cases (with the exception of A1) the gold(III) center is stabilized by the presence of at least two nitrogen ligands. The resulting gold(III) chromophores are of the following types: $\mathrm{AuN}_{4}\left(\right.$ B2), $\mathrm{AuN}_{3} \mathrm{Cl}$ (B1 and C3), $\mathrm{AuN}_{2} \mathrm{Cl}_{2}(\mathbf{C 2})$, and $\mathrm{AuN}_{2} \mathrm{O}_{2}(\mathbf{C 1})$.

For the dithiocarbamate complex, A1, the coordination of the esdt ligand takes place in a near square-planar geometry through the sulfur-donating atoms $\left(\mathrm{AuS}_{2} \mathrm{Br}_{2}\right)$, with the NCSS moiety coordinating the metal center in a bidentate symmetrical mode. The remaining coordination positions of the gold(III) chromophore are occupied by two halogen atoms (in cis) that may undergo facile aquation [29]. This structural hypothesis is also supported by density functional calculations previously carried out on some analogous gold(III)-dithiocarbamato complexes [51]. 
Table 1 Selected $\mathrm{Au}-\mathrm{X}$ bond distances (pm) of the gold(III) complexes

\begin{tabular}{|c|c|c|c|c|c|}
\hline Compound & Chemical formula & $\mathrm{Au}-\mathrm{N}(\mathrm{S})(\mathrm{pm})$ & $\mathrm{X}^{\mathrm{a}}$ & $\mathrm{Au}-\mathrm{X}(\mathrm{pm})$ & CIF \\
\hline \multirow[t]{2}{*}{ A1 } & \multirow[t]{2}{*}[\mathrm{Au}(\mathrm{esdt})\mathrm{Br}_{2}]{} & $230.2(2)$ & $\mathrm{Br}$ & $243.57(10)$ & \multirow[t]{2}{*}{641437} \\
\hline & & $231.9(2)$ & $\mathrm{Br}$ & $243.56(10)$ & \\
\hline \multirow[t]{2}{*}{ B1 } & \multirow[t]{2}{*}[\mathrm{Au}(\operatorname{dien})\mathrm{Cl}]{$\mathrm{Cl}_{2}$} & 204.8(8) & $\mathrm{N}$ & 205.1(8) & \multirow[t]{2}{*}{ DODXID } \\
\hline & & $201.0(8)$ & $\mathrm{Cl}$ & $227.8(3)$ & \\
\hline B2 & {$[\mathrm{Au}($ cyclam $)]\left(\mathrm{ClO}_{4}\right)_{2} \mathrm{Cl}$} & $204^{\mathrm{b}}$ & $\mathrm{N}$ & & POPKUA \\
\hline $\mathrm{C} 1$ & {$\left[\mathrm{Au}(\right.$ bipy $\left.)(\mathrm{OH})_{2}\right] \mathrm{PF}_{6}$} & & & & NA \\
\hline \multirow[t]{2}{*}{ C2 } & \multirow[t]{2}{*}[\mathrm{Au}(\text{phen})\mathrm{Cl}_{2}]{$\mathrm{Cl}$} & 203.3(8) & $\mathrm{Cl}$ & $226.3(3)$ & \multirow[t]{2}{*}{ QIRRAK } \\
\hline & & 205.6(8) & $\mathrm{Cl}$ & 226.6 & \\
\hline \multirow[t]{2}{*}{$\mathbf{C 3}$} & \multirow[t]{2}{*}[\mathrm{Au}(\text{terpy})\mathrm{Cl}]{$\mathrm{Cl}_{2}$} & $202.9(6)$ & $\mathrm{N}$ & $201.8(6)$ & \multirow[t]{2}{*}{ BUYMOX } \\
\hline & & 193.1(7) & $\mathrm{Cl}$ & $226.9(2)$ & \\
\hline D1 & {$\left[\mathrm{Au}\left(\right.\right.$ bipy $\left.\left.^{\mathrm{dmb}}-\mathrm{H}\right)(\mathrm{OH})\right] \mathrm{PF}_{6}$} & & & & NA \\
\hline \multirow[t]{2}{*}{ D2 } & \multirow[t]{2}{*}[\mathrm{Au}(\mathrm{bipy}^{\mathrm{dmb}}-\mathrm{H})(\mathrm{NHC}_{6}\mathrm{H}_{3}\mathrm{Me}_{2}-2,6)]{$\mathrm{PF}_{6}$} & $212.8(2)$ & $\mathrm{C}$ & $201.8(2)$ & \multirow[t]{2}{*}{ EJIXOK } \\
\hline & & $205.6(2)$ & $\mathrm{N}$ & $201.5(2)$ & \\
\hline \multirow[t]{2}{*}{ E1 } & \multirow[t]{2}{*}[\mathrm{Au}_{2}(\text{bipy})_{2}(\mathrm{m}-\mathrm{O})_{2}]{$\left(\mathrm{PF}_{6}\right)_{2}$} & $200.0(4)$ & $\mathrm{O}$ & 197.1(5) & \multirow[t]{2}{*}{642541} \\
\hline & & 201.5(4) & $\mathrm{O}$ & 195.7(6) & \\
\hline \multirow[t]{2}{*}{ E2 } & \multirow[t]{2}{*}[\mathrm{Au}_{2}(\mathrm{bipy}^{\mathrm{Me}})_{2}(\mathrm{m}-\mathrm{O})_{2}]{$\left(\mathrm{PF}_{6}\right)_{2}^{\mathrm{c}}$} & $201^{\mathrm{d}}$ & $\mathrm{O}$ & 198 & \multirow[t]{2}{*}{642542} \\
\hline & & 205 & $\mathrm{O}$ & 195 & \\
\hline $\mathbf{E 3}$ & trans $-\left[\mathrm{Au}_{2}\left(\text { bipy }^{\text {neoPen }}\right)_{2}(\mathrm{~m}-\mathrm{O})_{2}\right]\left(\mathrm{PF}_{6}\right)_{2}$ & 201.1(4) & $\mathrm{O}$ & 196.1(3) & \multirow{3}{*}{642543} \\
\hline \multirow[t]{2}{*}{$\mathbf{E 4}$} & \multirow[t]{2}{*}{ trans- $\left[\mathrm{Au}_{2}\left(\text { bipy }^{\mathrm{oXyl}}\right)_{2}(\mathrm{~m}-\mathrm{O})_{2}\right]\left(\mathrm{PF}_{6}\right)_{2}$} & 202.3(7) & $\mathrm{O}$ & 197.7(6) & \\
\hline & & 208.1(7) & $\mathrm{O}$ & 196.2(6) & \\
\hline $\mathbf{E 5}$ & {$\left[\mathrm{Au}_{2}\left(\mathrm{bipy}^{\mathrm{Me}, \mathrm{Me}}\right)_{2}(\mathrm{~m}-\mathrm{O})_{2}\right]\left(\mathrm{PF}_{6}\right)_{2}$} & $206.5(6)$ & $\mathrm{O}$ & $195.5(5)$ & 642544 \\
\hline
\end{tabular}

See "Introduction" and Fig. 1 for a description of the compounds and the ligands

CIF Crystallographic Information File, NA not available

a Atom in trans

b Average value

c An approximately 1:1 mixture of the cis and trans isomers

${ }^{\mathrm{d}}$ Data (average values) of the cis isomer

Notably, the X-ray structure of complex A1 confirms the structural hypothesis.

Compounds E1, E2, E3, E4, and E5 are dinuclear gold(III) complexes characterized by the presence of a dioxo bridge, with terminal bipyridyl ligands. Gold(III) chromophores of the $\mathrm{AuN}_{2} \mathrm{O}_{2}$ type are present in all cases. Notably, the $\mathrm{Au} \cdots \mathrm{Au}$ distances are quite small, being around $3.0 \AA$ [52]. The structural features and the reactivity of these dinuclear gold(III) complexes were analyzed in depth with the aid of detailed density functional theory analyses [52].

Compounds D1 and D2 are mononuclear organogold(III) compounds characterized by the presence of one carbon-gold bond. This feature greatly stabilizes the gold(III) oxidation state as previously pointed out for various cycloaurated derivatives and this is shown, inter alia, by an electrochemical study carried out on the chloride precursor of $\mathbf{D} 1$ and $\mathbf{D 2}$, [ $\left.\mathrm{Au}\left(\mathrm{bipy}^{\mathrm{dmb}}{ }_{-} \mathrm{H}\right) \mathrm{Cl}_{1}\right] \mathrm{PF}_{6}$ [53]. The resulting chromophores are of $\mathrm{AuCN}_{2} \mathrm{O}$ or $\mathrm{AuCN}_{3}$ type. Distortion from the ideal square-planar geometry observed in complex D2 — and most likely present also in
D1 - is imposed by the limited flexibility of the tridentate substituted bipyridine ligand [44-46].

\section{Solution chemistry}

Detailed solution studies were previously performed on all the compounds. In general, these compounds manifest sufficient solubility in aqueous media (with the exception of A1, which is soluble in organic solvents) and exhibit relatively intense charge transfer bands in the region 300$450 \mathrm{~nm}$. Spectrophotometric analysis revealed for most of the compounds (with the exception of A1 and D2) a high stability of the gold(III) chromophore, owing to the large stabilization effects brought about by the various multidentate ligands. Thus, no major alterations of the main visible bands were detected over $24 \mathrm{~h}$ of observation at $37{ }^{\circ} \mathrm{C}$, in phosphate buffer, $\mathrm{pH} 7.4$ (the largest observed decreases were indeed less than $10-15 \%)$. Some minor spectral changes, which are detected with time, may be attributed to simple ligand replacement reactions (usually 
replacement of halide ligands by water or hydroxo molecules) leading to modest chromophoric alterations.

In contrast, compounds $\mathbf{A} 1$ and $\mathbf{D 2}$ showed significant spectral modifications that are diagnostic of a lower intrinsic stability. In the case of A1, the relevant timedependent spectral changes were ascribed to the occurrence of redox processes and to associated structural modifications [29]; at variance, the spectral changes that are quickly observed for $\mathbf{D} 2$ upon dissolution in aqueous media are explained in terms of the rapid detachment of the xylidine ligand [54].

Compounds $\mathbf{C 2}$ and $\mathbf{C 3}$ manifest some spectral alterations over $24 \mathrm{~h}$ of observation. These spectral changes may be accounted for in terms of release of the halide ligand and occurrence of dimerization reactions [30].

As commonly found for several other metallodrugs, these gold(III) compounds behave as classic "prodrugs." In other words they require a "chemical activation" process, i.e., a specific chemical transformation before they can react with biomolecular targets; only the "activated species" is able to bind the target and produce the pharmacological effects. Accordingly, lack of chemical activation results in poor target reactivity and scarce biological activity, as found for $\mathbf{B 2}$ [30].

In four cases activation is most likely achieved through release of a halide ligand from the tetracoordinated gold(III) chromophore (A1, B1, C2, and C3); hydroxide is a less labile ligand and might be released only following proton exchange and conversion to a water molecule $(\mathbf{C 1}$ and D1). Alternatively, activation may occur through a reductive step, as these compounds still manifest appreciable oxidizing properties at the gold(III) center. This is most likely the case for the binuclear oxo-bridged compounds [52]. In some cases a mixed activation mechanism (redox plus aquation) might be operative.

\section{Electrochemistry}

Electrochemical profiles were previously investigated for most of the compounds of the tested ensemble. In all cases irreversible redox processes were found to take place; reductions occurred at potentials considerably below the typical value of the gold(III)/gold(I) couple known for the corresponding $\mathrm{KAuX}_{4}(\mathrm{X}$ is $\mathrm{Cl}, \mathrm{Br}$ ) halide precursors $\left(E^{\circ} \sim 1.29 \mathrm{~V}\right)$ [55]. It was also shown that the measured reduction potentials greatly depend on the nature of the gold(III) chromophore, being, for instance, very sensitive to halide replacement by hydroxide, this resulting in a large electrochemical variability. Among the compounds investigated, $\mathbf{C 1}(E=-0.60 \mathrm{~V})$ appears to be the most stable in oxidation state +3 , whereas $\mathbf{C 3}(E=+0.62 \mathrm{~V})$ is a compound exhibiting pronounced oxidizing properties. The oxidizing power of the cyclometallated derivatives D1 and
D2 can be extrapolated from that of the parent compound $\left[\mathrm{Au}\left(\mathrm{bipy}^{\mathrm{dmb}}-\mathrm{H}\right) \mathrm{Cl}\right] \mathrm{PF}_{6}$, with a reduction potential, in $\mathrm{MeCN}$ solvent, of $-0.97 \mathrm{~V}$ versus $\mathrm{Fc}^{+/ 0}$ (where $\mathrm{Fc}$ is ferrocene), using a platinum working electrode [53]. Owing to their appreciable oxidizing properties, most of the above-mentioned gold(III) compounds are quite easily reduced by biological reductants such as glutathione and ascorbic acid. In contrast, compound $\mathbf{B} 2$ displays a fairly negative redox potential and was found to be very stable toward reduction [30]. Finally, it was established that the presence of a single carbon-gold bond confers a great redox stability on the gold(III) center, which cannot be reduced in the presence of excess ascorbic acid (e.g., see the case of $\mathbf{C 1}$ with respect to D1) [31].

Very recently, detailed electrochemical data were reported for the dinuclear gold(III) complexes (compounds E1, E2, E3, E4, and E5) [52]. Notably, a good correlation was evidenced between redox reactivity and cytotoxicity: indeed, in the studies reported herein, E5, the compound with the highest redox potential, was ranked top on the basis of tumor selectivity and antitumor potency (see later). In any case, E1, E2, E3, E4, and E5 were shown to undergo reduction in the presence of glutathione and ascorbic acid at physiologically relevant concentrations.

\section{Biology}

\section{In vitro antitumor activity and tumor selectivity}

The cytotoxic properties of the compounds were previously established toward a few selected tumor cell lines, in particular the A2780 ovarian cancer cell line, both sensitive and resistant to cisplatin. On the whole, appreciable antiproliferative effects were measured on this cell line for all compounds, with the exception of $\mathbf{B 2}$. A compilation of the cytotoxic properties of gold compounds toward the A2780 cell line was recently reported [16]. However, owing to the fact that the compounds were only studied for a single cell line, it is not possible to define the overall spectrum of activity of the compounds or their possible selectivity.

The cytotoxic properties of the compounds investigated were therefore evaluated according to the following strategy. All the aforementioned 13 gold(III) complexes, auranofin $(\mathbf{F 1})$, and two free ligands (L1, L2) were initially analyzed on a 12-cell-line panel available at Oncotestaccording to the monolayer assay-for their in vitro antitumor activity. The monolayer assay assesses the antitumor potency and the selectivity of substances. The 12 most promising compounds (including the two free ligands) were then tested in the wider Oncotest 36-cell-line panel (see the electronic supplementary material for details) and evaluated by the $\mathrm{IC}_{70}$ mean graph analysis. As an example, Fig. 2 displays the $\mathrm{IC}_{70}$ mean graph of E5. In the $\mathrm{IC}_{70}$ 


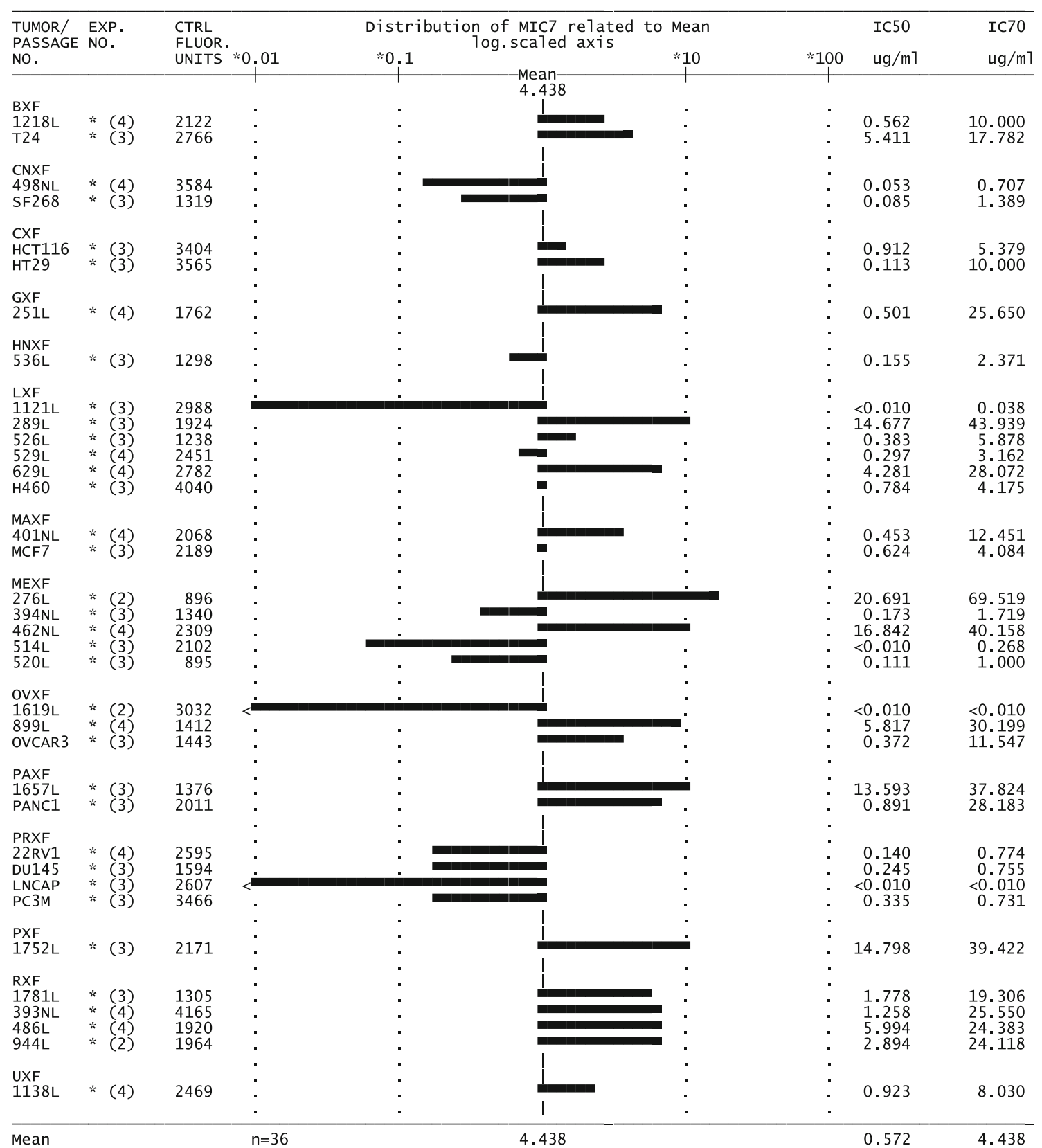

Fig. 2 Anticancer activity of compound $\mathbf{E 5}$ in a panel of 36 cell lines ( $\mathrm{IC}_{70}$ mean graph)

mean graph presentation, variations of the $\mathrm{IC}_{70}$ values of individual cell lines from the mean value are expressed as bars for the logarithmically scaled axis. Bars to the left demonstrate $\mathrm{IC}_{70}$ values lower than the mean value (cells are more sensitive than the average). Bars to the right demonstrate less sensitivity than the average of all cells. Arrows show that with the concentrations indicated the $\mathrm{IC}_{70}$ value was not achieved. $\mathrm{IC}_{50}$ and $\mathrm{IC}_{70}$ values were calculated from the median test/control values of two to four independent experiments in which triplicate determinations were taken. As is apparent from the $\mathrm{IC}_{70}$ mean graph presentation, compound $\mathbf{E 5}$ effected an excellent activity and selectivity score (mean $\mathrm{IC}_{70}=4.4 \mu \mathrm{g} / \mathrm{ml}$ ). Notably, CNS and prostate cancer as well as melanoma were particularly sensitive, whereas pancreatic and renal cancers were more resistant. $\mathrm{IC}_{70}$ mean graphs for the other compounds are given in Figs. S1-S15.

Table 2 summarizes the most relevant results obtained for all compounds as inferred from the overall analysis of cytotoxicity data (from both 36- and 12-cell-line tests). Gold compounds are ranked according to their cytotoxic potency and tumor selectivity. Indeed, in line with previous studies, we believe that selectivity is the most meaningful parameter; thus, selectivity was the primary criterion to arrange the 
Table 2 In vitro anticancer potency, tumor selectivity, and results of Compare analysis results for selected gold compounds

\begin{tabular}{|c|c|c|c|c|c|c|}
\hline \multirow[t]{2}{*}{ Compound } & \multicolumn{2}{|l|}{ Potency } & \multicolumn{3}{|c|}{ Tumor selectivity } & \multirow[t]{2}{*}{ Indicated MoA by Compare analysis } \\
\hline & $\begin{array}{l}\text { Mean IC } \mathrm{IC}_{50} \\
(\mu \mathrm{g} / \mathrm{ml})\end{array}$ & $\begin{array}{l}\text { Mean IC } \mathrm{IC}_{70} \\
(\mu \mathrm{g} / \mathrm{ml})\end{array}$ & Selective $/$ total & $\begin{array}{l}\text { Selective } \\
(\%)\end{array}$ & Rating $^{\mathrm{b}}$ & \\
\hline $\mathbf{E 5}$ & 0.572 & 4.44 & $10 / 36$ & 28 & +++ & HDAC inhibition \\
\hline A1 & 0.066 & 0.169 & $6 / 36$ & 17 & ++ & Negative ( $\rho<0.6$ for all reference compounds) \\
\hline F1 & 0.090 & 0.228 & $5 / 36$ & 14 & ++ & Proteasome, DNA synthesis \\
\hline D2 & 5.92 & 12.9 & $4 / 36$ & 11 & ++ & mTOR, DNA synthesis \\
\hline $\mathbf{E 3}$ & 8.76 & 21.8 & $4 / 36$ & 11 & ++ & Negative ( $\rho<0.6$ for all reference compounds) \\
\hline $\mathrm{C1}$ & 9.92 & 22.6 & $5 / 36$ & 14 & ++ & PKC inhibition \\
\hline E1 & 10.7 & 24.3 & $5 / 36$ & 14 & ++ & PKC inhibition \\
\hline $\mathrm{C2}$ & 0.370 & 1.02 & $2 / 36$ & 6 & + & CDK inhibition \\
\hline $\mathbf{E 4}$ & 4.45 & 13.1 & $2 / 36$ & 6 & + & HDAC inhibition \\
\hline $\mathbf{C 3}$ & 0.031 & 0.069 & $0 / 36$ & 0 & - & HDAC inhibition, alkylating agent \\
\hline $\mathbf{L 1}$ & 2.81 & 5.93 & $0 / 36$ & 0 & - & CDK inhibition \\
\hline $\mathbf{L 2}$ & 6.71 & 15.1 & $1 / 36$ & 3 & - & Eg5 inhibition \\
\hline $\mathbf{E 2}$ & 25.5 & 51.9 & $1 / 12$ & 8 & + & ND \\
\hline D1 & 27.7 & 50.4 & $0 / 12$ & 0 & - & ND \\
\hline B1 & 32.2 & 59.8 & $0 / 12$ & 0 & - & ND \\
\hline B2 & $>100$ & $>100$ & $0 / 12$ & 0 & - & ND \\
\hline
\end{tabular}

Compounds E2, D1, B1, and B2 were tested only in a 12-cell-line panel. Owing to their weak activity, no further profiling in Oncotest's 36-cellline panel was performed. The other compounds were tested in Oncotest's 36 cell lines, allowing subsequent Compare analysis

$M o A$ mechanism of action, $H D A C$ histone deacetylase, $m T O R$ mammalian target of rapamycin, $P K C$ protein kinase $\mathrm{C}$, $C D K$ cyclin-dependent kinase, $N D$ not done

${ }^{\mathrm{a}}$ Individual $\mathrm{IC}_{70}$ less than one third of the mean $\mathrm{IC}_{70}$; for example, if the mean $\mathrm{IC}_{70}$ is $2.1 \mu \mathrm{M}$, the threshold for above-average sensitivity was $\mathrm{IC}_{70}<0.7 \mu \mathrm{M}$

${ }^{\mathrm{b}}-$, percent selective $\leq 4 ;+, 4>$ percent selective $\geq 10 ;++, 10>$ percent selective $\geq 20 ;+++$, percent selective $>20$

overall scoring of the gold compounds tested. Notably, compounds E5, A1, F1, D2, E3, C1, and E1 turned out to be the best performers, all showing relevant cytotoxic properties and a moderate to excellent degree of selectivity.

\section{Compare analysis and possible modes of action}

Using the results from the 36-cell-line test, we carried out Compare analysis versus 110 reference substances (a list of the 110 reference compounds is in the electronic supplementary material) with known mechanisms of action (all tested in these 36 cell lines). This allowed us to draw some hypotheses concerning the likely mechanism of action of the compounds. The proposed mechanisms are presented in the last column of Table 2 .

The most significant findings for the various gold compounds are described below. Importantly, Compare analysis revealed striking similarities to various histone deacetylase (HDAC) inhibitors for E5, i.e., $\rho=0.72$ for both the benzamide acetyldinaline and the cyclic peptide apicidin and $\rho=0.61$ for suberic bishydroxamate on the $\mathrm{IC}_{70}$ level [42].

Displaying a mean $\mathrm{IC}_{70}$ value of $0.17 \mu \mathrm{g} / \mathrm{ml}$, A1's $\mathrm{IC}_{70}$ profile clearly differed from that of E5. Cell lines derived from cancer of the CNS (2/2) and the ovary (3/3) were particularly sensitive, whereas prostate and lung cancer cell lines were more resistant. Oncotest's Compare analysis showed no significant similarities to any of the standard agents, indicating that compound A1's mechanism of action was not covered by the 110 reference compounds used in this Compare analysis. Possibly, a new and unknown mechanism may be in operation. Previous studies had suggested that A1 might act on the proteasome or alternatively on thioredoxin reductase [27].

With respect to compound F1's antitumor activity, its overall potency (mean $\mathrm{IC}_{70}=0.23 \mu \mathrm{g} / \mathrm{ml}$ ) and the pronounced activity toward bladder cancer and melanoma are most remarkable. Compare analysis revealed $\rho=0.65$ ( $\mathrm{IC}_{50}$ Compare) and $\rho=0.60$ ( $\mathrm{IC}_{70}$ Compare) to tyropeptin $\mathrm{A}$, suggesting inhibition of proteasome as a possible mechanism of action.

Compounds D2 (mean $\mathrm{IC}_{70}=13 \mu \mathrm{g} / \mathrm{ml}$ ) and $\mathbf{E 3}$ (mean $\mathrm{IC}_{70}=22 \mu \mathrm{g} / \mathrm{ml}$ ) exhibited relatively weak potency, and a remarkable tumor selectivity profile. No positive correlation to any of the 110 reference compounds was detected by Compare analysis for $\mathbf{E 3}(\rho<0.6)$. The $\mathrm{IC}_{70}$ profile of D2 showed similarities to the mammalian target of rapamycin (mTOR) inhibitor rapamycin $(\rho=0.62)$ and the 
DNA intercalating compound (inhibition DNA synthesis) echinomycin A $(\rho=0.61)$.

Compounds $\mathbf{C 1}$ and $\mathbf{E 1}$ showed a nearly identical $\mathrm{IC}_{70}$ profile. A Spearman rank correlation [42] of the $\mathrm{IC}_{70}$ profiles of the two compounds revealed $\rho=0.91$, indicating strong similarity (Table S1). This finding might be reasonably explained by assuming that $\mathbf{E 1}$ in solution may rapidly break down and convert into $\mathbf{C 1}$, in a way its monomeric form. Pairwise, their potencies on the level of the mean $\mathrm{IC}_{50}$ and $\mathrm{IC}_{70}$ values were similar. Compare analysis indicated inhibition of protein kinase $\mathrm{C}$ (PKC) as the likely mechanism of action. For both compounds the PKC inhibitor UCN-01 (7-hydroxystaurosporine) was ranked top ( $\rho=0.68$ for $\mathbf{C 1}$ and $\rho=0.65$ for $\mathbf{E} 1$ on the $\mathrm{IC}_{70}$ level).

All other compounds showed only weak tumor selectivity. Noticeably, C3 was highly potent (mean $\mathrm{IC}_{70}=0.069 \mu \mathrm{g} / \mathrm{ml}$ ) and Compare analysis indicated HDAC inhibition as the likely mechanism of action. C2 (mean $\mathrm{IC}_{70}=1.0 \mu \mathrm{g} / \mathrm{ml}$ ) and the ligand $\mathbf{L 1}$ (mean $\left.\mathrm{IC}_{70}=5.9 \mu \mathrm{g} / \mathrm{ml}\right)$ possibly act by inhibition of cyclindependent kinase $(\mathrm{CDK})$. E4 (mean $\mathrm{IC}_{70}=13 \mu \mathrm{g} / \mathrm{ml}$ ) was suggested to act as an HDAC inhibitor and L2 (mean $\mathrm{IC}_{70}=15 \mu \mathrm{g} / \mathrm{ml}$ ) as an inhibitor of Eg5 [56]. But it must be considered that the lower the $\mathrm{IC}_{70}$ profile of a compound, the lower the reliability of the Compare analysis.

Overall, Compare analysis of the gold(III) compounds tested suggests the occurrence of a large variety of molecular mechanisms, most of them being proposed here for the first time. These results most likely imply that the final effect of these gold metallodrugs (i.e., cell death) may be achieved through interference with several and very different biochemical pathways and targets, in line with the intrinsic high reactivity of these gold compounds. In a few cases, however, common mechanisms of action have emerged, as summarized below. Table S1 gives the Spearman rank correlation of 12 out of the 16 compounds tested, based on the $\mathrm{IC}_{70}$ values as determined in the 36 cell lines. Remarkably, this analysis revealed the following major clusters:

1. Group 1: compounds E5, E4, and C3. The mechanism of action possibly involves HDAC inhibition.

2. Group 2: compounds $\mathbf{C 1}$ and E1. The mechanism of action is possibly $\mathrm{PKC}$ inhibition similar to staurosporine.

3. Group 3: compound C2. Low selectivity; the mechanism of action possibly involves inhibition of CDK.

4. Group 4: compounds D2 and F1. The mechanism of action is open, possibly inhibition of mTOR, proteasome, and/or DNA synthesis.

Notably, two well-known biomolecular systems such as $\mathrm{HDAC}$ and $\mathrm{PKC} /$ staurosporine are proposed here for the first time as probable targets for gold compounds. HDACs are nuclear proteins involved in histone regulation, whose inhibition includes growth arrest and the induction of differentiation $[57,58]$. Conversely, PKC is a very important family of serine/threonine kinases involved in the transduction of signals for cell proliferation, differentiation, apoptosis, and angiogenesis. Unsurprisingly, disruption of $\mathrm{PKC}$ regulation is implicated in tumorigenesis and drug resistance $[59,60]$. These findings open the way to a more specific and direct evaluation of selected gold compounds toward the targets mentioned. It is worthwhile mentioning that also the mTOR/rapamycin system, which is again a protein kinase that controls cell growth by regulating many cellular processes, including protein synthesis and autophagy [61], has emerged from Compare mechanistic analysis, as a possible target for gold compounds. In one case, inhibition of serine/threonine protein kinases (CDK), which play an important role in cell-cycle regulation [62], was implicated in the mechanism. On the other hand, cisplatin, oxaliplatin, carboplatin, and tetraplatin were included in the list of reference compounds; however, Compare analysis did not indicate significant $(\rho>0.6)$ correlation of any of the gold compounds to any of the conventional platinum compounds.

\section{Conclusions}

During the last few years, the interest of researchers working in the field of metallodrugs has progressively shifted from classic platinum compounds to unconventional platinum agents and to various series of non-platinum metallodrugs as it is increasingly evident that innovative anticancer activities may only arise from a metal with different chemistry and reactivity.

Within this frame, much attention is being paid to novel gold(III) compounds as they appear to be very attractive candidate anticancer agents on the grounds of their outstanding cytotoxic properties and peculiar chemistry. However, the biological data reported so far on gold(III) compounds have been obtained on very few human tumor cell lines and in a rather fragmented way. We performed here a more systematic analysis of their cytotoxic properties in vitro, relying on a large and representative tumor cell line panel, to offer a more solid basis for further pharmacological development. In addition, we could take advantage of the large amount of structural and chemical information already available on the various gold(III) compounds included in the test ensemble.

Overall the results reported strongly support the view that gold(III) compounds are potent cytotoxics and deserve greater attention as potential anticancer agents. Notably, the significant cytotoxic effects that were measured in the course of this investigation largely confirmed the very 
satisfactory results previously obtained on the A2780 cell line. At the same time, a quite large variability in the cytotoxic potency of the various complexes was highlighted as the average cytotoxicity values were found to range between 0.1 and $50 \mu \mathrm{M}$. A rather complicated pattern emerged from our results in terms of tumor selectivity. In a few cases, a relevant tumor selectivity was found, whereas in most cases selectivity was usually low (seven out of the 16 test compounds showed a high score of selectivity). Compounds E5 and A1, ranking first and second in the score, are the best candidates for further pharmacological testing; in contrast, $\mathbf{C 3}$, although being the most cytotoxic, exhibits a very poor selectivity and is thus positioned in tenth place.

Analysis of the biological data obtained and their comparison with chemical and structural data allowed us to identify some initial structure-function relationships. A first evident relationship has emerged between reactivity (e.g., redox properties, stability in aqueous solution) and cytotoxicity. The type of correlation is evident within the homogeneous series of binuclear compounds, where E5, the most reactive one, is also the one exhibiting the greatest cytotoxicity. Similar arguments can be applied to $\mathbf{C 3}$ and B2. C3, displaying a high reactivity, is also very cytotoxic; in contrast, B2, showing a poor chemical reactivity, is nearly devoid of cytotoxic effects. Notably, in the cases mentioned, reactivity broadly correlates with the measured redox potential, but one must use much caution in generalizing these statements.

Compare analysis of the measured cell growth inhibition data of gold(III) compounds in comparison with 110 standard agents with a known mechanism of action allowed us to gain some specific insight into the underlying molecular mechanisms, which appear to be numerous and heterogeneous. On the whole, the various gold(III) complexes are poorly correlated to one another, with a few exceptions. The postulated mechanisms are profoundly different from those of platinum drugs (where DNA is the primary target) but also from the mechanism of auranofin (F1). In any case, further experimental work is now warranted to validate these hypotheses on the isolated targets.

Acknowledgments We gratefully acknowledge support from Ente Cassa di Risparmio di Firenze and from the Italian Consortium C.I.R.C.M.S.B. C.G. wishes to thank AIRC for providing her with a Research Fellowship. A.C. thanks the Swiss National Science Foundation for financial support (project number PZ00P2_121933).

\section{References}

1. Barnes KR, Lippard SJ (2004) Met Ions Biol Syst 42:143-177

2. Reedijk J (2003) Proc Natl Acad Sci USA 100:3611-3616
3. Wang D, Lippard SJ (2005) Nat Rev Drug Discov 4:307-320

4. Sigel A, Sigel H (2004) Metal ions in biological systems. Marcel Dekker, New York

5. Sigel A, Sigel H (2005) Metal ions in biological systems. Wiley, New York

6. Jakupec M, Keppler BK (2004) In: Sigel A, Sigel H (ed) Metal ions in biological systems. Marcel Dekker, New York

7. Bruijnincx PCA, Sadler PJ (2008) Curr Opin Chem Biol 12:197206

8. Alessio E, Mestroni G, Bergamo A, Sava G (2004) Curr Top Med Chem 4:1525-1535

9. Ang WH, Dyson PJ (2006) Eur J Inorg Chem 4003-4018

10. Milacic V, Fregona D, Dou QP (2008) Histol Histopathol 23:101-108

11. Casini A, Hartinger C, Gabbiani C, Mini E, Dyson PJ, Keppler BK, Messori L (2008) J Inorg Biochem 102:564-575

12. Parish RV, Howe BP, Wright JP, Mack J, Pritchard RG, Buckley RG, Elsome AM, Fricker SP (1996) Inorg Chem 35:1659-1666

13. Parish RV, Mack J, Hargreaves L, Wright JP, Buckley RG, Elsome AM, Fricker SP, Theobald BRC (1996) J Chem Soc Dalton Trans 69-74

14. Giovagnini L, Ronconi L, Aldinucci D, Lorenzon D, Sitran S, Fregona D (2005) J Med Chem 48:1588-1595

15. Che CM, Sun RWY, Yu WY, Ko CB, Zhu NY, Sun HZ (2003) Chem Commun 1718-1719

16. Gabbiani C, Casini A, Messori L (2007) Gold Bull 40:73-81

17. Carotti S, Marcon G, Marussich M, Mazzei T, Messori L, Mini E, Orioli P (2000) Chem Biol Interact 125:29-38

18. Ronconi L, Marzano C, Zanello P, Corsini M, Miolo G, Macca C, Trevisan A, Fregona D (2006) J Med Chem 49:1648-1657

19. Rigobello MP, Messori L, Marcon G, Cinellu MA, Bragadin M, Folda A, Scutari G, Bindoli A (2004) J Inorg Biochem 98:16341641

20. Saggioro D, Rigobello MP, Paloschi L, Folda A, Moggach SA, Parsons S, Ronconi L, Fregona D, Bindoli A (2007) Chem Biol 14:1128-1139

21. Rigobello MP, Scutari G, Folda A, Bindoli A (2004) Biochem Pharmacol 67:689-696

22. Rackham O, Nichols SJ, Leedman PJ, Berners-Price SJ, Filipovska A (2007) Biochem Pharmacol 74:992-1002

23. Omata Y, Folan M, Shaw M, Messer RL, Lockwood PE, Hobbs D, Bouillaguet S, Sano H, Lewis JB, Wataha JC (2006) Toxicol In Vitro 20:882-890

24. Barnard PJ, Berners-Price SJ (2007) Coord Chem Rev 251:1889_ 1902

25. Engman L, McNaughton M, Gajewska M, Kumar S, Birmingham A, Powis G (2006) Anticancer Drugs 17:539-544

26. Wang Y, He QY, Sun RW, Che CM, Chiu JF (2005) Cancer Res 65:11553-11564

27. Milacic V, Chen D, Ronconi L, Landis-Piwowar KR, Fregona D, Dou QP (2006) Cancer Res 66:10478-10486

28. Wang Y, He QY, Che CM, Tsao SW, Sun RW, Chiu JF (2008) Biochem Pharmacol 75:1282-1291

29. Ronconi L, Giovagnini L, Marzano C, Bettio F, Graziani R, Pilloni G, Fregona D (2005) Inorg Chem 44:1867-1881

30. Messori L, Abbate F, Marcon G, Orioli P, Fontani M, Mini E, Mazzei T, Carotti S, O'Connell T, Zanello P (2000) J Med Chem 43:3541-3548

31. Marcon G, Carotti S, Coronnello M, Messori L, Mini E, Orioli P, Mazzei T, Cinellu MA, Minghetti G (2002) J Med Chem 45:1672-1677

32. Abbate F, Orioli P, Bruno B, Marcon G, Messori L (2000) Inorg Chim Acta 311

33. Coronnello M, Mini E, Caciagli B, Cinellu MA, Bindoli A, Gabbiani C, Messori L (2005) J Med Chem 48:6761-6765 
34. Casini A, Cinellu MA, Minghetti G, Gabbiani C, Coronnello M, Mini E, Messori L (2006) J Med Chem 49:5524-5531

35. Paull KD, Shoemaker RH, Hodes L, Monks A, Scudiero DA, Rubinstein L, Plowman J, Boyd MR (1989) J Natl Cancer Inst 81:1088-1092

36. Huang RL, Wallqvist A, Covell DG (2005) Biochem Pharmacol 69:1009-1039

37. Boyd MR, Paull KD, Rubinstein LR (1992) In: Valeriote FA, Corbett T, Backer L (eds) Cytotoxic anticancer models and concepts for drug discovery and development. Kluwer, Amsterdam, pp 11-34

38. Roth T, Burger AM, Dengler W, Willmann H, Fiebig HH (1999) In: Fiebig HH, Burger AM (eds) Contrib oncol, pp 145-156

39. Fiebig HH, Dengler WA, Roth T (1999) In: Fiebig HH, Burger AM (eds) Contrib Oncol, pp 29-50

40. Fiebig HH, Berger DP, Dengler WA, Wallbrecher E, Winterhalter BR (1992) In: Fiebig HH, Berger DP (eds) Relevance of tumor models for anticancer drug development. Karger, Basel, pp 321-351

41. Dengler WA, Schulte J, Berger DP, Mertelsmann R, Fiebig HH (1995) Anti Cancer Drugs 6:522-532

42. Fang XL, Shao L, Zhang H, Wang SM (2004) J Chem Inf Comput Sci 44:249-257

43. Elder RC, Watkins JW (1986) Inorg Chem 25:223-226

44. Kimura E, Kurogi Y, Koike T, Shionoya M, Iitaka Y (1993) 28:33-49

45. Hollis LS, Lippard SJ (1983) J Am Chem Soc 105:4293-4299

46. Cinellu MA, Minghetti G, Pinna MV, Stoccoro S, Zucca A, Manassero M, Sansoni M (1998) J Chem Soc Dalton Trans 17351741
47. Cinellu MA, Minghetti G, Pinna MV, Stoccoro S, Zucca A, Manassero M (2000) J Chem Soc Dalton Trans 8:1261-1265

48. Cinellu MA, Zucca A, Stoccoro S, Minghetti G, Manassero M, Sansoni M (1996) J Chem Soc Dalton Trans 4217-4225

49. Cinellu MA, Minghetti G, Pinna MV, Stoccoro S, Zucca A, Manassero M (1999) J Chem Soc Dalton Trans 2823-2831

50. Cinellu MA, Minghetti G, Pinna MV, Stoccoro S, Zucca A, Manassero M (2003) Eur J Inorg Chem 2304-2310

51. Ronconi L, Maccato C, Barreca D, Saini R, Zancato M, Fregona D (2005) Polyhedron 24:521-531

52. Gabbiani C, Casini A, Messori L, Guerri A, Cinellu MA, Mlnghetti G, Corsini M, Rosani C, Zanello P, Arca M (2008) Inorg Chem 47:2368-2379

53. Sanna G, Pilo MI, Spano N, Minghetti G, Cinellu MA, Zucca A, Seeber R (2001) J Organomet Chem 622:47-53

54. Messori L, Marcon G, Cinellu MA, Coronnello M, Mini E, Gabbiani C, Orioli P (2004) Bioorg Med Chem 12:6039-6043

55. Koelle U, Laguna A (1999) Inorg Chim Acta 290:44-50

56. Castillo A, Morse HC, Godfrey VL, Naeem R, Justice MJ (2007) Cancer Res 67:10138-10147

57. Horn D (2008) Adv Exp Med Biol 625:81-86

58. Hadnagy A, Beaulieu R, Balicki D (2008) Mol Cancer Ther 7:740-748

59. Ali AS, Ali S, El-Rayes BF, Philip PA, Sarkar FH (2009) Cancer Treat Rev 35:1-8

60. Mackay HJ, Twelves CJ (2007) Nat Rev Cancer 7:554-562

61. Guertin DA, Sabatini DM (2005) Trends Mol Med 11:353-361

62. Sharma PS, Sharma R, Tyagi R (2008) Curr Cancer Drug Targets 8:53-75 